\title{
Stress-relaxation and fatigue behaviour of synthetic brow-suspension materials
}

Kyung-Ah Kwon ${ }^{\mathrm{a},{ }^{*}}$, Rebecca J. Shipley ${ }^{\mathrm{a}}$, Mohan Edirisinghe ${ }^{\mathrm{a}}$, Andrew W. Rayment ${ }^{\mathrm{b}}$, Serena M. Best ${ }^{\mathrm{b}}$, Ruth E. Cameron ${ }^{\mathrm{b}}$, Tahrina Salam ${ }^{\mathrm{c}}$, Geoffrey E. Rose ${ }^{\mathrm{c}}$, Daniel G. Ezra ${ }^{\mathrm{c}}$

${ }^{a}$ Department of Mechanical Engineering, University College London, Torrington Place, London, WC1E 7JE, UK

${ }^{\mathrm{b}}$ Department of Materials Science and Metallurgy, Cambridge Centre for Medical Materials, University of Cambridge, 27 Charles Babbage Road, Cambridge, CB3 OFS, UK

${ }^{c}$ Moorfields Eye Hospital, UCL Institute of Ophthalmology NIHR Biomedical Research Centre for Ophthalmology, 162 City Road, London, EC1V 2PD, UK

*Corresponding author. Tel.: +44 207679 2193. E-mail address: j.kwon@ucl.ac.uk

\begin{abstract}
Ptosis describes a low position of the upper eyelid. When this condition is due to poor function of the levator palpebrae superioris muscle, responsible for raising the lid, "browsuspension" ptosis correction is usually performed, which involves internally attaching the malpositioned eyelid to the forehead musculature using brow-suspension materials. In service, such materials are exposed to both rapid tensile loading and unloading sequences during blinking, and a more sustained tensile strain during extended periods of closure. In this study, various mechanical tests were conducted to characterise and compare some of commonly-used synthetic brow-suspension materials (Prolene ${ }^{\circledR}$, Supramid Extra ${ }^{\circledR}$ II, Silicone rods (Visitec ${ }^{\circledR}$ Seiff frontalis suspension set) and Mersilene ${ }^{\circledR}$ mesh) for their time-dependent response. At a given constant tensile strain or load, all of the brow-suspension materials exhibited stress-relaxation or creep, with Prolene ${ }^{\circledR}$ having a statistically different relaxation or creep ratio as compared with the others. Uniaxial tensile cyclic tests through preconditioning and fatigue tests demonstrated drastically different time-dependent response amongst the various materials. Although the tests generated hysteresis force-strain loops for all materials, the mechanical properties such as the number of cycles required to reach the steady-state, the reduction in the peak force, and the cyclic energy dissipation varied considerably. To reach the steady-state, Prolene ${ }^{\circledR}$ and the silicone rod required the greatest and the least number of cycles, respectively. Furthermore, the fatigue tests at physiologically relevant conditions (15\% strain controlled at $6.5 \mathrm{~Hz})$ demonstrated that the reduction in the peak force during
\end{abstract}


100000 cycles ranged from 15 to 58\%, with Prolene ${ }^{\circledR}$ and the silicone rod exhibiting the greatest and the least value, respectively.

Many factors need to be considered to select the most suitable brow-suspension material for ptosis correction. These novel data on the mechanical time-dependent performance could, therefore help to guide clinicians in their decision-making process for optimal surgical outcome.

\section{Introduction}

Ocular health requires regular blinking to clean and lubricate the ocular surface, and to protect the eye from any irritants or harmful objects. When a blink was examined using a high-speed camera, it was found that it consisted of four phases; closing, closed, earlyopening and late-opening, depending on the upper eyelid motion (Kwon et al. 2013). The opening motion of upper eyelids was seen to be divided into two phases (early- and lateopening), depending on how much original palpebral aperture was recovered; early-opening and late-opening accounting for $97 \%$ and $100 \%$ recovery, respectively. For a healthy volunteer without any eye diseases it was measured that one full blink (from closing to lateopening phases) took $\sim 600 \mathrm{~ms}$ although it only took $\sim 300 \mathrm{~ms}$ for the one near-full blink (from closing to early-opening phases).

The closing and opening upper eyelid motions are primarily controlled by ocular muscles called orbicularis oculi (OO) and levator palpebrae superioris (LPS), respectively. Hence, when the LPS is maldeveloped or injured owing to accidents, tumours or loss of innervation, a drooping upper eyelid becomes manifest, and this is referred to as "ptosis". This eye condition results in disfigurement, headaches, visual impairment, and even irreversible sensory deprivation amblyopia, severe cases effectively leading to blindness in infants (Dutton 1989; Fox 1980).

Severe ptosis with minimal LPS muscle function is generally treated by brow-suspension surgery, which involves subcutaneously attaching the malpositioned upper eyelid to the frontalis muscle using a brow-suspension material (Dutton 1989; Fox 1980). Synthetic browsuspension materials, along with biological fascia lata, are widely used during this type of surgery but the former are often favoured because of their wide availability, freedom from the need to harvest the graft, less operative time and low risk of infection. Monofilament polypropylene Prolene ${ }^{\circledR}$ (Chow et al. 2011; Manners et al. 1994), multifilament polyamide Supramid Extra ${ }^{\circledR}$ (Katowitz 1979; Kook et al. 2004) and silicone rods (Carter et al. 1996; Lee et al. 2009; Leone et al. 1981) are a few examples of such synthetic materials. Depending on 
a patient's age, condition and intended implant duration, a surgeon intuitively selects the most appropriate brow-suspension material in order to achieve the best surgical outcome.

During the "brow-suspension" surgery, the selected material is tied at an "open-eye" position. Hence, the brow-suspension material will undergo a rapid loading and unloading sequence during a blink, induced by the action of the OO muscle, thereby rapidly stretching and relaxing the material. In addition, during more prolonged periods of closure, the material will be subjected to a more sustained strain resulting both from the weight of eyelid tissues and the resting muscle tone. The tensile mechanical properties of brow-suspension materials are, therefore, of great importance. Single uniaxial tensile properties of some of commonly-used synthetic brow-suspension materials were studied by Kwon et al. (2014), who reported significant different tensile properties such as elastic modulus, ultimate tensile strength and work of fracture among the materials. These synthetic brow-suspension materials are, however, polymer-based and hence have a viscoelastic response to loading and unloading and a study of the time-dependent mechanical properties such as stress-relaxation, creep and fatigue merit characterisation. Some researchers have studied the stress-relaxation and creep properties of some synthetic surgical sutures such as Prolene ${ }^{\circledR}$, Supramid ${ }^{\circledR}$, Mersilene ${ }^{\circledR}$, Ticron ${ }^{\circledR}$ (multifilament polyester) and Ethilon ${ }^{\circledR}$ (polyamide monofilament), and found that the time-dependent behaviour varied greatly among different suture materials (Holmlund 1976; Vizesi et al. 2008). In addition to different types of suture materials, mechanical testing conditions such as temperature, cyclic frequency and pre-set load or strain influence how the suture materials respond over time (Dao and Dicken 1987; Sauer and Richardson 1980; Vizesi et al. 2008).

To date, there has been no study comparing the viscoelastic properties of synthetic browsuspension materials used for ptosis repair. This study investigates such properties for some of the commonly-used synthetic brow-suspension materials, by conducting stress-relaxation and creep tests within a physiological strain or load range. Furthermore, preconditioning and fatigue tests were performed to see the effect of repetitive loading-unloading sequences on the mechanical properties of the materials. This work, carried out in collaboration with clinicians, might help guide the selection of brow-suspension materials on a more scientific foundation rather than by intuition alone.

\section{Materials}

The following synthetic brow-suspension materials were purchased and mechanically tested soon after removal from the packaging (Table 1): 
4-0 monofilament polypropylene (Prolene ${ }^{\circledR}$; Ethicon Ltd, UK)

3-0 sheathed twisted polyamide (Supramid Extra ${ }^{\circledR}$ II; S. Jackson Inc., USA)

Silicone frontalis suspension rod (Visitec ${ }^{\circledR}$ Seiff frontalis suspension set (Visitec ${ }^{\circledR}$ SFSS);

Beaver-Visitec International Ltd., UK),

Woven polyester mesh (Mersilene ${ }^{\circledR}$ mesh; Ethicon Ltd., UK)

\section{Methods}

Three specimens of each brow-suspension material were investigated in each test described below and all the tests were performed at $22.0 \pm 0.6^{\circ} \mathrm{C}$ with $45.0 \pm 3.2 \%$ humidity.

\subsection{Stress-relaxation}

Stress-relaxation tests for the materials were performed using Tinius Olsen Universal Test machine (Tinius Olsen Ltd., Salfords, Surrey, England) controlled by a computer software (Horizon, Tinius Olsen Ltd., Surrey, England). A 250N load cell was used for Prolene ${ }^{\circledR}$, Supramid Extra ${ }^{\circledR}$ II and Mersilene ${ }^{\circledR}$ mesh while a $5 \mathrm{~N}$ load cell was used for Visitec ${ }^{\circledR}$ SFSS.

Each specimen was mounted securely using apposing rectangular clamps with rubber contact surfaces with a gauge length of $10 \mathrm{~mm}$. In order to avoid any slippage of the thin suture type materials (Prolene ${ }^{\circledR}$ and Supramid Extra ${ }^{\circledR}$ II), they were first wound around a $10 \mathrm{~mm}$-long wooden piece several times before mounting onto the machine using the clamps. Upon the secure mount onto the machine, each specimen was elongated $1.5 \mathrm{~mm}$ at $10 \mathrm{~mm} / \mathrm{min}$, then was held at the displacement for 30 minutes, continuously recording the induced force.

The relaxation ratio and the force reduction in percentage of each material were calculated using the following formula:

$$
\begin{aligned}
& \text { Relaxation ratio }=F(\text { ini }) / F(\text { end }) \\
& \text { Force reduction }(\%)=[F(\text { ini })-F(\text { end })] / F(\text { ini }) * 100
\end{aligned}
$$

where $F$ (ini) is the force induced from the initial $1.5 \mathrm{~mm}$ elongation and $F$ (end) is the force measured after the 30-minute stress-relaxation period.

\subsection{Creep}

Creep tests for the various materials were performed using the same machine and the software as in the stress-relaxation tests. A $5 \mathrm{~N}$ load cell was used for all the materials and each sample was mounted in the same manner as for the stress-relaxation testing.

Upon the secure mount of each specimen, it was extended until the induced force reached the desired force $(0.5 \mathrm{~N}$ or $2 \mathrm{~N})$ at $1 \mathrm{~N} / \mathrm{s}$, then the specimen was set to maintain the force over a 
period of 30 minutes, continuously recording the displacement. The recorded displacement values were converted to strain values based on the gauge length of $10 \mathrm{~mm}$.

The creep ratio of each material was calculated using the following formula:

$$
\text { Creep ratio }=D(\text { end }) / D(\text { ini })
$$

where $D$ (ini) is the displacement measured when the desired force was first reached, and $D($ end) is the displacement measured after the 30 minutes creep period.

\subsection{Preconditioning}

Preconditioning tests for the materials were performed using the same machine, load cells and software as for the stress-relaxation tests. Upon the secure mount of each specimen as described in the stress-relaxation tests, a displacement-controlled triangular waveform was applied at $10 \mathrm{~mm} / \mathrm{min}$ with $15 \%$ strain (=1.5 mm displacement). The strain and the induced force were recorded continuously for 100 cycles and the force recorded was converted to engineering stress by dividing the induced force by the initial apparent specimen dimensions. For each loading-unloading cycle per specimen, the peak force was determined and the secant modulus was evaluated by dividing the corresponding stress of the peak force by the corresponding strain at that peak force. In addition, cyclic energy dissipation was evaluated by calculating the area of the hysteresis loop enclosed by the loading and unloading stressstrain curve. The number of cycles required to reach the steady-state was also recorded, the steady-state being identified when the values of both the peak force and the cyclic energy dissipation stabilised.

\subsection{Fatigue}

Uniaxial displacement-controlled fatigue tests for the materials were performed using a servo-hydraulic testing machine (Mayes, Instron) fitted with a $1 \mathrm{~kg}$ load cell (Miniature SBeam Load Cell DBBSMM - 1 kg, Applied Measurements Ltd., Reading, UK).

When each specimen was mounted securely in the same manner as the stress-relaxation tests, it underwent the program (Table 2) set up by WaveMaker ${ }^{\mathrm{TM}}$ Editor in Instron 8800 controller. The holding segments both at the beginning and the end were introduced to stabilise the system and the second segment of ramping was necessary to avoid any tensile breakage of the specimens.

The load and displacement data were collected using an A/D converter and were recorded by LabVIEW (National Instruments Corporation (U.K.) Ltd, Newbury, Berkshire). As described in the preconditioning tests, the peak force, its corresponding stress, secant modulus and 
cyclic energy dissipation were evaluated for each cycle. The first cycle was defined as the first loading-unloading sequence after the ramping and unloading at the beginning.

\subsection{Statistical analysis}

All statistical analysis was conducted with one-way analysis of variance (ANOVA) using the software package Origin 9.0 (OriginLab Corporation, Northampton, MA 01060, USA). The Tukey test was applied to compare the significant difference among the measured mechanical properties of the synthetic brow-suspension materials. $\mathrm{P}<0.05$ was considered to be statistically significant.

\section{Results}

\subsection{Stress-relaxation}

Figure 1 shows how the force changed over time when each of the synthetic brow-suspension materials was stretched to $15 \%$ strain and then held at that position.

The stretch to the desired strain at $10 \mathrm{~mm} / \mathrm{min}$ resulted in an instant increase in force for all the materials, reaching their peak forces. Over the relaxation period, there was an early rapid reduction in force, followed by a more gradual decay towards a plateau. For all the materials except Prolene ${ }^{\circledR}$, the first phase of rapid reduction lasted less than 60 seconds of the relaxation period, reaching the plateau after $\sim 10$ minutes. This most rapid decay in force for Prolene ${ }^{\circledR}$ appeared to last $\sim 10$ minutes, followed by a gradual decay that extended beyond the 30 minutes relaxation period - a plateau not being reached for Prolene ${ }^{\circledR}$.

Figure $1 \mathrm{~b}$ illustrates how the normalised force for each material changes over the period of relaxation: The four distinct curves for the materials clearly demonstrate different force relaxation responses and consequently different stress relaxation response over the relaxation time. However, Visitec ${ }^{\circledR}$ SFSS, Mersilene ${ }^{\circledR}$ mesh and Supramid Extra ${ }^{\circledR}$ II appeared to exhibit a similar relaxation trend, but with varying degrees in force reduction at the end of the relaxation period.

Table 3 summarises the stress relaxation test results such as peak force, percentage force reduction after the relaxation period and relaxation ratio for the test materials.

The stretch to $15 \%$ strain resulted in the peak force of $0.3 \mathrm{~N}$ for Visitec ${ }^{\circledR}$ SFSS while the value ranged from $4.1 \mathrm{~N}$ to $4.7 \mathrm{~N}$ for the rest of the materials. The percentage force reduction after the relaxation period was greatest for Prolene ${ }^{\circledR}$ with $70 \%$, and least for Visitec ${ }^{\circledR}$ SFSS with $22 \%$. With the exception of Mersilene ${ }^{\circledR}$ mesh and Supramid Extra ${ }^{\circledR}$ II $(p=0.06)$, the values for the percentage force reduction were all significantly different $(\mathrm{p}<0.05)$. Moreover, 
Prolene ${ }^{\circledR}$ alone had the statistically different $(\mathrm{p}<0.001)$ relaxation ratio (3.4) compared with the other materials, for which the ratio ranged from 1.3 to 1.7.

\subsection{Creep}

Figure 2 shows how the strain changed over time when each of the synthetic materials was stretched until the resultant load reached $0.5 \mathrm{~N}$ or $2 \mathrm{~N}$ and then held at that load for the 30 minutes creep period.

Regardless of the amplitude of the constant load, all the materials increased in length and consequently strains with varying degrees during the creep period. When the desired force was reached, Prolene ${ }^{\circledR}$ increased in length most rapidly compared with the others and, although the rate of increase slowed down over time, a steady-state was not reached during the 30 minutes period. Supramid Extra ${ }^{\circledR}$ II and Mersilene ${ }^{\circledR}$ mesh also elongated during the creep period, but both reached a stable length at $\sim 10$ minutes for the $0.5 \mathrm{~N}$ creep test or $\sim 5$ minutes for the $2 \mathrm{~N}$ test. Unlike the others, Visitec ${ }^{\circledR}$ SFSS exhibited a linear increase in strain over the creep period, but the overall increase in normalised strain was least of all the materials (Figure 2).

The initial strain and creep ratio for each of the brow-suspension materials are summarised in Table 4.

The resultant strain when the desired force was first attained (initial strain) varied greatly. It ranged from $1.3 \%$ to $43.6 \%$ for the $0.5 \mathrm{~N}$ testing, and from $7.8 \%$ to $275 \%$ for the $2 \mathrm{~N}$ creep testing, with Visitec ${ }^{\circledR}$ SFSS always being an order of magnitude greater than the other materials.

Prolene ${ }^{\circledR}$ gave a significantly different creep ratio compared with the others for both $0.5 \mathrm{~N}$ and $2 \mathrm{~N}$ creep tests $\left(\mathrm{p}<10^{-5}\right)$. While the creep ratio was 1.1-1.4 for the other materials (at both $0.5 \mathrm{~N}$ and $2 \mathrm{~N}$ constant loads), the value for Prolene ${ }^{\circledR}$ was 2.2 at $0.5 \mathrm{~N}$ constant load and 1.8 at 2N loading.

\subsection{Preconditioning}

Various curves obtained during preconditioning tests for synthetic brow-suspension materials are shown in Figures 3 to 6 and their results are summarised in Table 5.

Hysteresis loops are shown on the force-strain graphs for all the brow-suspension materials and the loops appeared to reach a steady-state with almost constant shape and area after a different number of cycles. Prolene ${ }^{\circledR}$ and Visitec ${ }^{\circledR}$ SFSS required the greatest and the least 
number of cycles with $\sim 90$ and $\sim 20$, respectively. Both Supramid Extra ${ }^{\circledR}$ II and Mersilene ${ }^{\circledR}$ mesh required intermediate values, namely $\sim 40$ and $\sim 60$, respectively.

After the first loading-unloading cycle, a toe-region on the force-strain graph was observed for all the brow-suspension materials except Visitec ${ }^{\circledR}$ SFSS. During the second loading cycle, the force was $\sim 0 \mathrm{~N}$ up to 5-6\% strain for Prolene ${ }^{\circledR}$, Supramid Extra ${ }^{\circledR}$ II and Mersilene ${ }^{\circledR}$ mesh while the force started to increase from $0 \%$ strain for Visitec ${ }^{\circledR}$ SFSS. Hence, Visitec ${ }^{\circledR}$ SFSS alone a exhibited distinctly different shape of hysteresis loop, which appeared to be more 'linear' with less area coverage compared with the others.

The force-strain curves were observed to shift down with subsequent loading-unloading cycles. When the peak force was evaluated per cycle then plotted against the number of cycles for all the materials (Figures 4), the evolution of peak force illustrated a rapid drop at the beginning followed by gradual leveling off towards the end of 100 cycles with varying levels of reduction. The level of reduction in the peak force was greatest for Prolene ${ }^{\circledR}$ with $\sim 28 \%$, followed by Mersilene ${ }^{\circledR}$ mesh ( 21\%), Supramid Extra ${ }^{\circledR}$ II and Visitec ${ }^{\circledR}$ SFSS with $\sim 12 \%$. A significant statistical difference was not found only for Supramid Extra ${ }^{\circledR}$ II and Visitec ${ }^{\circledR}$ SFSS $(\mathrm{p}=0.998)$.

Prolene $^{\circledR}$ and Supramid Extra ${ }^{\circledR}$ II had one and two orders of magnitude greater secant modulus than Mersilene ${ }^{\circledR}$ mesh and Visitec ${ }^{\circledR}$ SFSS, respectively (Figure 5a). Similar results were also seen for the values of cyclic energy dissipation, Prolene ${ }^{\circledR}$ and Supramid Extra ${ }^{\circledR}$ II exhibiting one to two orders of magnitude greater values than the others (Figure 6a). Regardless of this drastic difference in the values, the behaviour over the 100 cycle tests were the same, with a rapid decrease at the beginning followed by gradual leveling-off as the number of cycles increased (Figure $5 b$ and $6 b$ ).

\subsection{Fatigue}

The force-strain curves obtained during fatigue tests for the materials investigated in this work, together with various curves showing how mechanical properties such as peak force, secant modulus and cyclic energy dissipation change with increasing the number of cycles are illustrated in Figures 7 to 10. These results are summarised in Table 6.

No failure was observed for any of the materials after 100,000 cycles at $6.5 \mathrm{~Hz}$.

Hysteresis loops were visible for all materials, although Visitec ${ }^{\circledR}$ SFSS alone gave a different shape. While Prolene ${ }^{\circledR}$, Supramid Extra ${ }^{\circledR}$ II and Mersilene ${ }^{\circledR}$ mesh exhibited an oval-shaped loop with a smooth outline, Visitec ${ }^{\circledR}$ SFSS exhibited a loop with an undulating outline. 
Figure 7 illustrates the hysteresis loops at the 10-100000 cycles of fully reversed uniaxial fatigue tests at $15 \%$ strain. It demonstrates the downward shift of hysteresis loops with varying degrees for all the materials except for Visitec ${ }^{\circledR}$ SFSS. Visitec ${ }^{\circledR}$ SFSS maintained the mean force $(\sim 0.06 \mathrm{~N})$ throughout the entire fatigue test, resulting in hardly any changes in the values of peak force, secant modulus and cyclic energy dissipation throughout the entire 100000 cycles. Although the percentage reduction in the peak force between the tenth and the last cycle was evaluated to be $15.2 \pm 8.2 \%$ for Visitec ${ }^{\circledR}$ SFSS, the difference in the peak force was merely $0.02 \mathrm{~N}(=20 \mathrm{mN})$.

Prolene ${ }^{\circledR}$, Supramid Extra ${ }^{\circledR}$ II and Mersilene ${ }^{\circledR}$ mesh exhibited a decrease in the values of peak force, secant modulus and cyclic energy dissipation with increasing number of cycles. The decreasing trend was an initial rapid drop followed by a stabilised region where no further decrease was seen. The number of cycles to reach this stabilised region varied greatly, being 80000, 20000, 10000 and 60000 for Prolene ${ }^{\circledR}$, Supramid Extra ${ }^{\circledR}$ II, Visitec ${ }^{\circledR}$ SFSS and Mersilene ${ }^{\circledR}$ mesh, respectively.

By the end of 100,000 cycles the peak force decreased by $\sim 58 \%$ for Prolene ${ }^{\circledR}$ followed by Mersilene ${ }^{\circledR}$ mesh ( 42\%), Supramid Extra ${ }^{\circledR}$ II ( 22\%) and Visitec ${ }^{\circledR}$ SFSS ( 15\%). Moreover, pronounced different values in cyclic energy dissipation were seen at the end of 100,000 cycles. While Prolene ${ }^{\circledR}$ and Supramid Extra ${ }^{\circledR}$ II had 1-2 $\mathrm{MJ} / \mathrm{m}^{3}$ cyclic energy dissipation Visitec $^{\circledR}$ SFSS and Mersilene ${ }^{\circledR}$ mesh had two orders of magnitude less cyclic energy dissipation with $\sim 0.02 \mathrm{MJ} / \mathrm{m}^{3}$. The values of cyclic energy dissipation between Prolene ${ }^{\circledR}$ and Supramid Extra ${ }^{\circledR}$ II or Visitec ${ }^{\circledR}$ SFSS and Mersilene ${ }^{\circledR}$ mesh were not significantly different. These fatigue test results are summarised in Figure 11.

\section{Discussion}

\subsection{Choice of testing strain and load}

In this study, the time-dependent responses of synthetic brow-suspension materials were compared by performing stress relaxation and creep tests. The constant loads of $0.5 \mathrm{~N}$ and $2 \mathrm{~N}$ used for creep tests and the constant strain of 15\% used for stress relaxation tests were chosen based on exploratory experiments performed just prior to this work: Developing a method for direct measurement of orbicularis oculi (OO) strength is one of our on-going projects and the related preliminary results gave $0.2 \mathrm{~N}$ and $1.8 \mathrm{~N}$ for normal eyelid closure and forced eyelid closure, respectively. Moreover, Jacobs (1954) measured the OO strength to be $\sim 0.6-0.7 \mathrm{~N}$ by applying a cylinder-piston apparatus connected to a mercury manometer on a closed palpebral fissure of a healthy subject. Therefore, $0.5 \mathrm{~N}$ and $2 \mathrm{~N}$ were selected to simulate the 
forces that an implanted brow-suspension material is likely to encounter during normal blinking or forced eyelid closure, respectively. The constant strain of $15 \%$ used for stress relaxation tests was selected based on calculation for the most commonly-used browsuspension surgical configurations, namely Fox pentagon and Crawford triangle techniques. By analysing metrical data for the incision position of each configuration, we have found that, during blinking, the implanted materials were likely to undergo tensile strain of $16.0 \pm 0.9 \%$ and $25.5 \pm 1.7 \%$ for Fox pentagon and Crawford triangle, respectively. However, the forcestrain relationship obtained by uniaxially stretching the synthetic brow-suspension materials at $1500 \mathrm{~mm} / \mathrm{min}$ revealed that Prolene ${ }^{\circledR}$ and Supramid Extra ${ }^{\circledR}$ II needed 3.4-3.7N to result in 15\% strain (Kwon et al. 2014). These values are already greater than what the materials would seem to experience during a forced closure (namely $\sim 2 \mathrm{~N}$ ), and hence choosing the $15 \%$ strain as a tensile strain amplitude for strain-controlled mechanical tests is reasonable.

\subsection{Stress-relaxation}

The stress relaxation tests showed that the force required to maintain the strain of the materials decreased over time, but by varying degrees. A rapid initial stretch of a polymer material results in the increased internal stress in the material. However, when the material is held at a constant strain for a period of time, the polymer chain molecules rearrange themselves in order to stabilise and to minimise the internal stress, thereby reducing the resultant force and exhibiting stress relaxation response. All the materials except Prolene ${ }^{\circledR}$ exhibited a similar relaxation trend by reaching the steady-state at $\sim 10$ minutes of the relaxation time. No such steady-state was reached for Prolene ${ }^{\circledR}$, thereby resulting in the significantly greater percentage force reduction of $\sim 70 \%$ and relaxation ratio of 3.4 at the end of the 30 minute relaxation test period. This result agrees well with the other reports (Holmlund 1976; Vizesi et al. 2008) comparing the tension loss or relaxation ratio between Prolene ${ }^{\circledR}$ and nylon- or polyester-based suture materials.

\subsection{Creep}

The significantly different time-dependent response of Prolene ${ }^{\circledR}$ was also confirmed by creep tests, since Prolene ${ }^{\circledR}$ was found to have significantly greater normalised strain or creep ratio over the 30 minutes creep period as compared with the others - regardless of the amplitude of the constant load. The creep response at either $0.5 \mathrm{~N}$ or $2 \mathrm{~N}$ included both primary and secondary creep phases, with varying degrees for all the materials except Visitec ${ }^{\circledR}$ SFSS. The gradual increase in strain after the initial rapid increase corresponded to the primary creep 
phase with its increasing rate being slowed down over the creep period. This phase was followed by a near-constant creep curve, which corresponded to the secondary creep phase. Both of these phases could not be observed for Visitec ${ }^{\circledR}$ SFSS, since the strain increased in a linear fashion with time; this response possibly being attributable to the limits of the creep test machine and the program used in this study. The machine was a screw-driven type, and hence its load-controlling capacity might have been limited. Moreover, the test program was set up so that the load could be kept constant by applying a closed feedback loop. Once the desired load was attained, however, there was a sudden drop of force, namely $60-100 \mathrm{mN}$ for the $0.5 \mathrm{~N}$ test and $180-350 \mathrm{mN}$ for the $2 \mathrm{~N}$ creep test; this sudden drop happened at $80-100$ seconds after attaining the desired load and then gradually recovered over time. Irrespective of the desired load, recovery took place within 5 minutes for Supramid Extra ${ }^{\circledR}$ II and Mersilene ${ }^{\circledR}$ mesh, and within 10 minutes for Prolene ${ }^{\circledR}$. However, even after 30 minutes creep testing, Visitec ${ }^{\circledR}$ SFSS had still not recovered and this might be due to the highly resilient nature of the elastomer; unlike the other materials, the silicone rod has cross-linking bonds, which are likely to produce retractive force during the force-recovering period, thereby reducing the rate of recovery, and hence the longer time. In spite of this creep behaviour, Visitec ${ }^{\circledR}$ SFSS resulted in a near-constant normalised strain, thereby exhibiting the least creep ratio of 1.1 for both $0.5 \mathrm{~N}$ and $2 \mathrm{~N}$ creep tests. As with the stress-relaxation tests, a steady-state was not reached with the normalised strain-time graph for Prolene ${ }^{\circledR}$, and this significantly different creep ratio might be due to the relatively lower glass transition temperature, $T_{\mathrm{g}}$ and the structure of the material. While the $T_{g}$ of nylon and polyester associated with Supramid Extra $^{\circledR}$ II and Mersilene ${ }^{\circledR}$ mesh ranges from 50 to $80^{\circ} \mathrm{C}$, the $\mathrm{T}_{\mathrm{g}}$ of polypropylene associated with Prolene ${ }^{\circledR}$ is about $-20^{\circ} \mathrm{C}$ (Vizesi et al. 2008). Hence, at the ambient test temperature, the viscous fluidity would relatively dominate over the elastic solid nature of Prolene ${ }^{\circledR}$, thereby allowing for increased polymer chain mobility.

\subsection{Preconditioning and fatigue}

Any brow-suspension material implanted to repair severe ptosis will be subjected to a rapid tensile loading and unloading sequence during blinking, each cycle lasting $<1$ s. A human adult is considered to blink about 12 times per minute (Fatt and Weissman 1992), which means an implanted brow-suspension material would undergo 720 rapid tensile loading and unloading cycles per hour, or 17280 cycles per day. This frequency of loading underlines the importance of studying the mechanical properties of such materials with rapid and repeated loading and unloading sequences. 
During ptosis surgery, the synthetic brow-suspension materials are implanted in a 'virgin' state, and so it is of particular interest to see whether subsequent blinking action would lead to any changes in the mechanical properties of the implanted material, and, if so, then the question of how many blinks are required to reach the steady-state is of importance. This steady-state is known as the "preconditioned state”, where no further changes are observed. It is desirable for a brow-suspension material to have a small preconditioning cycle number, so that the implanted materials stabilize early to allow rapid assessment of the results of surgery (and appropriate action if the ptosis has been either overcorrected or undercorrected). Considering the average duration for the closing phase of a blink was reported to be $76 \pm 2 \mathrm{~ms}$ (Kwon et al. 2013), the frequency of $6.5 \mathrm{~Hz}$ was evaluated to be ideal for a tensile cyclic test to mimic the blinking action since it would take $76.9 \mathrm{~ms}$ for a double amplitude (i.e. for 0$15 \%$ strain in this study) at such frequency. However, this rapid stretch resulted in a tensile break of the brow-suspension materials and therefore the preconditioning tests had to be conducted at a much slower rate, whereby subsequent loading-unloading cycles could be applied without fracture of the materials. The rate of $10 \mathrm{~mm} / \mathrm{min}$ for the preconditioning tests was chosen due to the limits of the machine, so that the pre-set strain of $15 \%$ was accurately controlled, collecting adequate number of data points to see any effect of subsequent cycles. In the preconditioning tests, hysteresis loops were observed over the entire 100 cycles for all the materials. It is notable that the force-strain curve did not start from $0 \mathrm{~N}$ for the first loading cycle (Figure 3), this being because of a small force (0.07-0.3N) introduced when each specimen was clamped in the taut state. The plateau region between $0 \%$ and $5-6 \%$ strain during the second loading cycle for Prolene ${ }^{\circledR}$, Supramid Extra ${ }^{\circledR}$ II and Mersilene ${ }^{\circledR}$ mesh is likely to be due to an irreversible elongation, caused by the internal changes in the initial structure of the polymer materials in response to the first loading cycle. In addition to the internal change, the first loading cycle would have caused the alignment of polyester fibres in the direction of the applied loading, increasing the aspect ratio of oval shaped micrometresized pores in Mersilene ${ }^{\circledR}$ mesh and this external change in the mesh structure would also result in irreversible elongation.

In the fatigue tests, the machine was operated to its limit, thereby generating some artefacts in the data; these artefacts not being considered in this data analysis and explain some gaps between data points on the peak force, secant modulus and cyclic energy dissipation curves (Figure 8-10).

During the stress-relaxation tests, as well as both cyclic tests (preconditioning and fatigue), all of the materials were extended until 15\% strain was attained. When the force induced by 
this $15 \%$ strain was compared among the three different test methods, no significant difference was found between the force values for stress-relaxation tests and preconditioning tests; this result being expected as the material was extended at the same rate $(10 \mathrm{~mm} / \mathrm{min})$ in each test. A significant difference was, however, found for Prolene ${ }^{\circledR}$ and Supramid Extra ${ }^{\circledR}$ II when they were stretched at $1 \mathrm{~mm} / \mathrm{s}(60 \mathrm{~mm} / \mathrm{min})$ during the fatigue tests, i.e. $4.0-4.3 \mathrm{~N}$ vs. 6.2N for Prolene ${ }^{\circledR}$ and 4.7-5.4N vs. 8.2N for Supramid Extra ${ }^{\circledR}$ II. This significant difference is caused by the different strain rates, since increasing strain rate has been reported to result in increasing peak force (Ching et al. 2000; Nilsson 1982). Each sample was stretched at $\times 6$ faster rate for fatigue tests than for stress-relaxation or preconditioning tests, thereby resulting in the significantly greater force. Neither Visitec ${ }^{\circledR}$ SFSS nor Mersilene ${ }^{\circledR}$ mesh showed this difference between test results, possibly due to the highly elastic nature for Visitec ${ }^{\circledR}$ SFSS and the mesh structure of Mersilene ${ }^{\circledR}$.

\subsection{Hysteresis loops in preconditioning and fatigue tests}

As shown in the preconditioning and fatigue tests, a loading-unloading cycle produces a hysteresis loop for all materials, confirming their viscoelastic nature; such hysteresis loops arising because of a difference between the energy absorbed by the material during loading and the energy released by the material during unloading. Energy is absorbed during loading to allow deformation of the material, and some of this absorbed energy is released by recoiling polymer chains during unloading; the energy difference between the two phases is known to be dissipated as heat.

Hysteresis loops for the preconditioning and fatigue tests were of different shape only with Visitec ${ }^{\circledR}$ SFSS and, unlike the three other materials, Visitec ${ }^{\circledR}$ SFSS also did not exhibit a toeregion on the force-strain graphs during preconditioning tests throughout the 100 cycles. Visitec ${ }^{\circledR}$ SFSS also demonstrated a narrower hysteresis loop than the other materials, suggesting that silicone rod has a relatively strong elastic response compared with others; this might also explain the requirement for the least number of preconditioning cycles with this material. The unusual shape of hysteresis loop in fatigue testing for Visitec ${ }^{\circledR}$ SFSS (Figure 7c) is likely to be due to machine effects, working at a high frequency with very low forces $(<130 \mathrm{mN})$. This unusual shape led to fluctuating values in peak force, secant modulus and cyclic energy dissipation (Figure 8-10). The fluctuating characteristic was much more pronounced for secant modulus values, since the corresponding strain at the peak force recorded per cycle would have varied substantially between $0 \%$ and $15 \%$ owing to the irregular hysteresis shape. Nevertheless, when the peak force per cycle was normalised for 
Visitec ${ }^{\circledR}$ SFSS, it appeared to follow a similar curve to that for Supramid Extra ${ }^{\circledR}$ II as shown in the preconditioning test results (Figure $4 \mathrm{~b}$ ).

\subsection{Mechanism of fatigue}

Except for Mersilene ${ }^{\circledR}$ mesh, the overall shape and structure of all brow-suspension materials were maintained in the fully-reversed uniaxial cyclic tests (including preconditioning), although the hysteresis loops became displaced down the force-axis with increasing cyclic repetition, indicating cyclic softening in the materials. This trend for decreased peak force, secant modulus and cyclic energy dissipation follows a three-stage pattern: the first stage with a substantial decrease in the values during early cycles, the second stage with a more gradual decrease, and the third stage with a stable state at which no further changes in the values occurred. For all materials the last stage of stability was reached at a different number of cycles, although all followed the three-stage pattern throughout the 100- or 100000-cyclic tests (Figure 4 and Figure 8). The cyclic softening of the materials is likely to be due to a combination of time-dependent stress-relaxation and fatigue damage. Our cyclic tests did not have a mean force of zero, and hence the time-dependent behavior of these viscoelastic materials is likely to contribute to the softening phenomenon. Fatigue damage during cyclic testing can be both mechanical and thermal (Sauer and Richardson 1980). During cyclic loading and unloading, a polymer will tend to reach a dynamic equilibrium by rearranging or realigning the polymer chains in the direction of loading and unloading; some chains might break or slide upon each other during this period, resulting in reduced material strength. Some surface abrasion or polymeric damage generated by interfibre friction during cyclic testing might also weaken the material. In addition to these mechanical contributions to fatigue damage, the cyclic loading and unloading could cause a temperature rise by hysteretic heating, thereby increasing the polymer chain movements and subsequently decreasing the strength of the material.

As the first closed hysteresis loop appeared at around cycle 10, this value was adopted for the peak force reduction calculations: The overall decrease in peak force between 10 and 100000 cycles was shown to be 57.8\%, 21.9\%, 15.2\% and 41.6\% for Prolene ${ }^{\circledR}$, Supramid Extra ${ }^{\circledR}$ II, Mersilene ${ }^{\circledR}$ mesh and Visitec ${ }^{\circledR}$ SFSS, respectively (Table 6). Prolene ${ }^{\circledR}$ exhibited the greatest reduction, but this is expected because of its different time-dependent stress-relaxation response. Moreover, Chen and Wong (2011) reported a rapid surface temperature rise from $25^{\circ} \mathrm{C}$ to $67^{\circ} \mathrm{C}$ with polypropylene specimens after 1200 cycles of strain-controlled fatigue testing at $5 \mathrm{~Hz}$; although the temperature stabilised at $50^{\circ} \mathrm{C}$ after 2000 cycles, it is still much 
higher than the glass transition temperature of this material. The greatest fatigue reduction seen with Prolene ${ }^{\circledR}$ could, there, be attributed to both mechanical and thermal changes. In contrast, the force reduction with Supramid Extra ${ }^{\circledR}$ II or Mersilene ${ }^{\circledR}$ mesh is thought to be dominated by a mechanical contribution, since they both have much greater glass transition temperatures than Prolene ${ }^{\circledR}$ (Vizesi et al. 2008). Both Mersilene ${ }^{\circledR}$ mesh and Supramid Extra ${ }^{\circledR}$ II are, however, multifilament materials and the interfibre friction during fast cyclic loading is likely to result in surface damage and a consequent reduction in peak force; surface damage with Mersilene ${ }^{\circledR}$ mesh might be greater than with Supramid Extra ${ }^{\circledR}$ II, as Mersilene ${ }^{\circledR}$ mesh exhibited a greater reduction in the peak force during both cyclic tests, whilst the converse was observed during stress-relaxation tests (Figure 4 and 8, compared with Figure 1). This significant difference would be due to their different structures. Whilst Supramid Extra $^{\circledR}$ II is formed by twisting nylon filaments into a thicker fibre, Mersilene ${ }^{\circledR}$ mesh is formed by inter-weaving polyester fibres into a mesh (as shown in scanning electron micrographs reported by Kwon et al. (2014)). Mersilene ${ }^{\circledR}$ mesh has much less contact area between the fibres, which might lead to more concentrated and more prominent surface damage during cyclic tests; the surface abrasion observed at the fibre-interconnected areas on Mersilene ${ }^{\circledR}$ mesh when rapidly loaded $(1500 \mathrm{~mm} / \mathrm{min}$ ) supports this hypotheses (Kwon et al. 2014). The lowest percentage force reduction was evaluated for Visitec ${ }^{\circledR}$ SFSS, with the mean reduction in force between the tenth and the last cycle being $0.02 \mathrm{~N}(20 \mathrm{mN})$.

For a given level of cyclic loading and unloading, a lower loss of modulus is associated with better resistance to fatigue (Echtermeyer et al. 1995; Pattin et al. 1996; Tang et al. 2004) and our work would suggest that Prolene ${ }^{\circledR}$ and Visitec ${ }^{\circledR}$ SFSS exhibit the poorest and the greatest resistance to fatigue, respectively, among the investigated brow-suspension materials.

Notably, the 1-2 orders of magnitude difference in secant modulus and cyclic energy dissipation among the various materials can be attributed to substantially different stress values owing to markedly different material sizes and geometries (Kwon et al. 2014).

\subsection{General Remarks}

The results reported in this study do not present the 'actual' values that an implanted synthetic brow-suspension material would experience, owing to limitations associated with the test model.

All of the tests were carried out in dry conditions, ignoring the in vivo environment of hydration at $37^{\circ} \mathrm{C}$ and at $\mathrm{pH} 7.4$. We would, however, suggest that the broad conclusions would be similar if performed in wet conditions at $37^{\circ} \mathrm{C}$; this speculation is based on the 
study reported by Vizesi et al. (2008) who performed stress-relaxation and creep tests in wet condition ( $0.9 \%$ phosphate-buffered saline solution) for some common suture materials, namely Prolene ${ }^{\circledR}$, Ethilon ${ }^{\circledR}$ (monofilament nylon) and Ticron $^{\circledR}$ (multifilament braided polyester fibre). These authors compared the stress-relaxation and creep ratios of each material at two different temperatures; room temperature $\left(22^{\circ} \mathrm{C}\right)$ vs. body temperature $\left(37^{\circ} \mathrm{C}\right)$ and found that increasing the temperature only had an effect on Prolene ${ }^{\circledR}$. When the effect of hydration is considered over the very long-term (years), there might be significant changes as Kook et al. (2004) reported severe morphological changes due to hydrolytic degradation in nearly a half of multifilament nylon (Supramid Extra) sutures removed at $>4$ years after implantation. The cyclic loading-unloading sequence only poorly mimics the complex, fourphase blinking profile, and the fatigue tests were limited to only 100000 cycles because of limited availability and high running costs of the testing rig. Assuming a blink rate of 12/min, however, the 100000 cycles tested represents less than a week of in vivo use. Much more sophisticated test rigs and machine time are required in order to overcome these limitations. Nevertheless, the current study provides a relatively good comparison of timedependent response to static and dynamic tensile loading among the synthetic browsuspension materials.

\section{Conclusions}

The time-dependent response of four commonly-used brow-suspension materials (Prolene ${ }^{\circledR}$, Supramid Extra ${ }^{\circledR}$ II, Visitec ${ }^{\circledR}$ SFSS, Mersilene ${ }^{\circledR}$ mesh) was characterised by stress-relaxation and creep tests. During the 30 minutes testing of stress-relaxation or creep, Prolene ${ }^{\circledR}$ (in contrast to the other materials) exhibited a significantly different time-dependent response with significantly greater relaxation or creep ratio, as well as a longer duration to reach the stabilised condition.

In addition to these static time-dependent characteristics, dynamic characterisation was performed by applying fully-reversed strain-controlled cyclic testing. Irrespective of the differences in the size, geometry and structure of the brow-suspension materials, they all demonstrated hysteresis loops and the loops were found to shift down in the force-strain graph with increasing number of cycles. The fatigue tests for $10^{5}$ cycles at a physiologically relevant strain and speed revealed that the number of preconditioning cycles required to reach the dynamically stabilised condition and also the percentage reduction in the values of peak force, secant modulus and cyclic energy dissipation varied significantly between the various materials. 
The fatigue and viscoelastic properties of some of commonly-used synthetic brow-suspension materials presented in this study have direct clinical implications. During brow suspension ptosis correction, precise setting of the eyelid position is key to a successful outcome. Our investigations suggest that even if an eyelid is set appropriately at surgery, the variable and sometimes marked time-dependent lengthening of these materials may result in a late undercorrection, as has been commonly reported. An understanding of the different timedependent responses of these materials by oculoplastic surgeons might help to direct choice of materials and improve surgical results.

\section{Acknowledgements}

This study was supported by a knowledge exchange and enterprise funding ("Discovery to use”) to the authors at University College London (UCL). Authors Ezra and Rose acknowledge funding by the Department of Health through the National Institute for Health Research to Moorfields Eye Hospital NHS Foundation Trust and UCL Institute of Ophthalmology Biomedical Research Centre. All the mechanical testing was performed at Cambridge University and we are very grateful for the facilities provided.

\section{References}

Carter, S.R., Meecham, W.J. and Seiff, S.R., 1996. Silicone frontalis slings for the correction of blepharoptosis: indications and efficacy. Ophthalmology. 103, 623-630.

Chen, P. and Wong, S.-C., 2011. Strain-controlled fatigue life and modeling of conduit polymers. J. Mater. Sci. 46, 1902-1912.

Ching, E.C.Y., Li, R.K.Y. and Mai, Y.-W., 2000. Effects of gauge length and strain rate on fracture toughness of polyethylene terephthalate glycol (PETG) film using the essential work of fracture analysis. Polym. Eng. Sci. 40, 310-319.

Chow, K., Deva, N. and Ng, S.G.J., 2011. Prolene frontalis suspension in paediatric ptosis. Eye. 25, 735-739.

Dao, K.C. and Dicken, D.J., 1987. Fatigue failure mechanisms in polymers. Polym. Eng. Sci. 27, 271-276.

Dutton, J.J., 1989. A color atlas of ptosis: A practical guide to evaluation and management, P.G. Publishing Pre Ltd., Lucky Plaza, Singapore.

Echtermeyer, A.T., Engh, B. and Buene, L., 1995. Lifetime and Young's modulus changes of glass/phenolic and galss/polyester composites under fatigue. Composites. 26, 10-16. 
Fatt, I. and Weissman, B.A., 1992. Physiology of the eye: an introduction to the vegetative functions, Second ed. Butterworth-Heinemann, a division of Reed Publishing (USA) Inc., USA.

Fox, S.A., 1980. Surgery of Ptosis, The Williams \& Wilkins Company, Baltimore, USA.

Holmlund, D.E.W., 1976. Physical properties of surgical suture materials: Stress-strain relationship, stress-relaxation and irreversible elongation. Ann. Surg. 184, 189-193.

Jacobs, H.B., 1954. Strength of the orbicularis oculi. Brit. J. Ophthalmol. 38, 560-566.

Katowitz, J.A., 1979. Frontalis suspension in congenital ptosis using a polyfilament, cabletype suture. Arch. Ophthalmol. 97, 1659-1663.

Kook, K.H., Lew, H., Chang, J.H., Kim, H.Y., Ye, J. and Lee, S.Y., 2004. Scanning electron microscopic studies of Supramid Extra from the patients displaying recurrent ptosis after frontalis suspension. Am. J. Ophthalmol. 138, 756-763.

Kwon, K.-A., Shipley, R.J., Edirisinghe, M., Ezra, D.G., Rose, G., Best, S.M. and Cameron, R.E., 2013. High-speed camera characterization of voluntary eye blinking kinematics. J. R. Soc. Interface. 10, 20130227.

Kwon, K.-A., Shipley, R.J., Edirisinghe, M., Ezra, D.G., Rose, G.E., Rayment, A.W., Best, S.M. and Cameron, R.E., 2014. Microstructure and mechanical properties of synthetic brow-suspension materials. Mater. Sci. Eng. C Mater. Biol. Appl. 35, 220-230.

Lee, M.J., Oh, J.Y., Choung, H.-K., Kim, N.J., Sung, M.S. and Khwarg, S.I., 2009. Frontalis sling operation using silicone rod compared with preserved fascia lata for congenital ptosis. Ophthalmology. 116, 123-129.

Leone, C.R.J., Shore, J.W. and Van Gemert, J.V., 1981. Silicone rod frontalis sling for the correction of blepharoptosis. Ophthalmic Surg. 12, 881-887.

Manners, R.M., Tyers, A.G. and Morris, R.J., 1994. The use of prolene as a temporary supensory material for brow suspension in young children. Eye. 8, 346-348.

Nilsson, T., 1982. Effect of strain rate on tensile strength and strain of surgical suture materials. Scand. J. Plast. Reconstr. Surg. 16, 97-100.

Pattin, C.A., Caler, W.E. and Carter, D.R., 1996. Cyclic mechanical property degradation during fatigue loading of cortical bone. J. Biomech. 29, 69-79.

Sauer, J.A. and Richardson, G.C., 1980. Fatigue of polymers. Int. J. Fracture. 16, 499-532.

Tang, S.M., Cheang, P., AbuBakar, M.S., Khor, K.A. and Liao, K., 2004. Tension-tension fatigue behavior of hydroxyapatite reinforced polyetheretherketone composites. Int. J. Fatigue. 26, 49-57. 
Vizesi, F., Jones, C., Lotz, N., Gianoutsos, M. and Walsh, W.R., 2008. Stress relaxation and creep: Viscoelastic properties of common suture materials used for flexor tendon repair. J. Hand Surg. 33A, 241-246. 


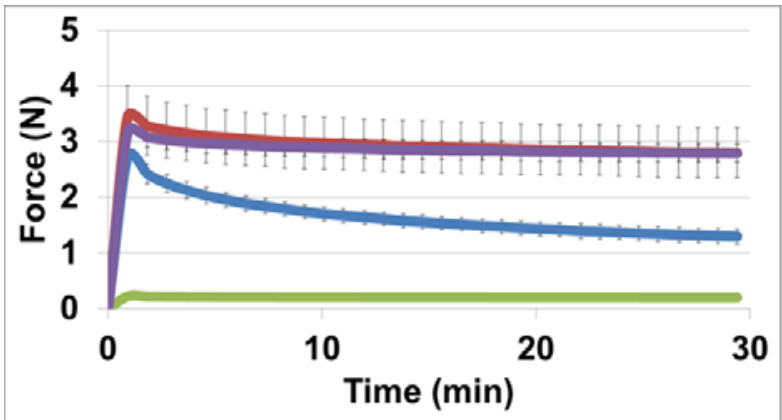

-Prolene -Supramid Extra II

-Visitec SFSS

(a)

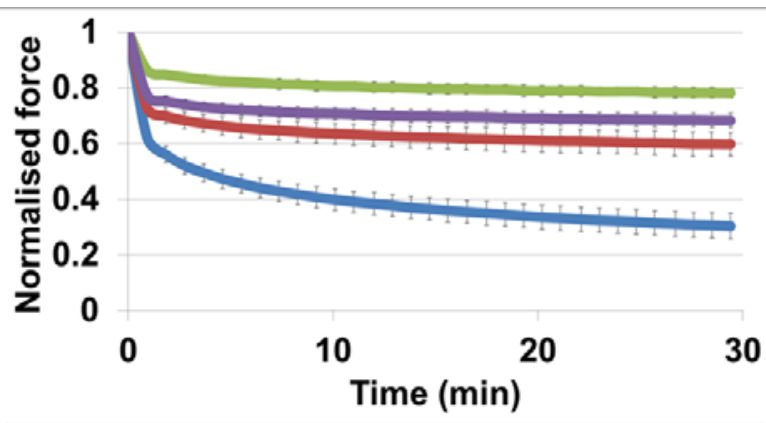

-Prolene Supramid Extra II

-Visitec SFSS - Mersilene mesh

(b)

Figure 1: Stress-relaxation curves over 30 minutes relaxation period for synthetic browsuspension materials (a) averaged force-time graph (b) normalised force-time graph
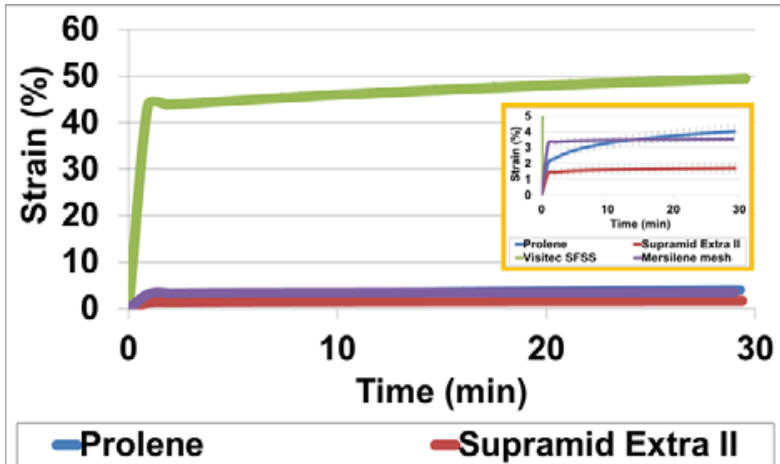

-Visitec SFSS -Mersilene mesh

(a)
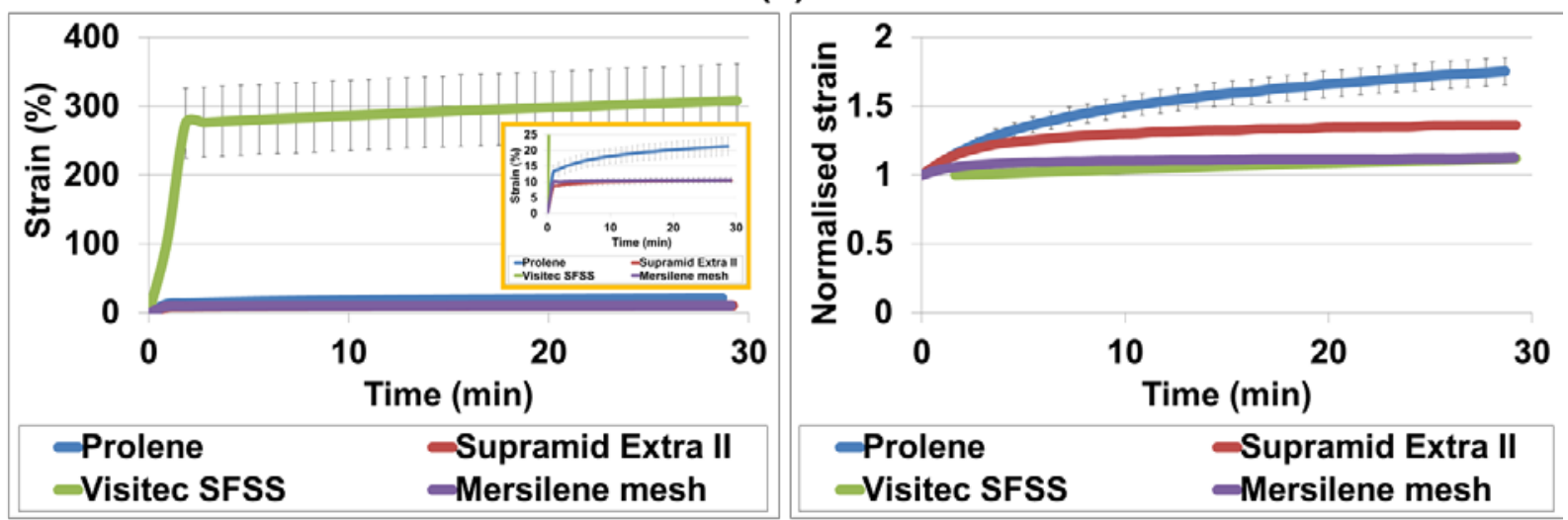

(b)

Figure 2: Averaged strain-time and normalised strain-time creep curves over 30 minutes creep period at (a) $0.5 \mathrm{~N}$ constant force (b) $2 \mathrm{~N}$ constant force (the insets depict the strain-time curves at a smaller scale) 


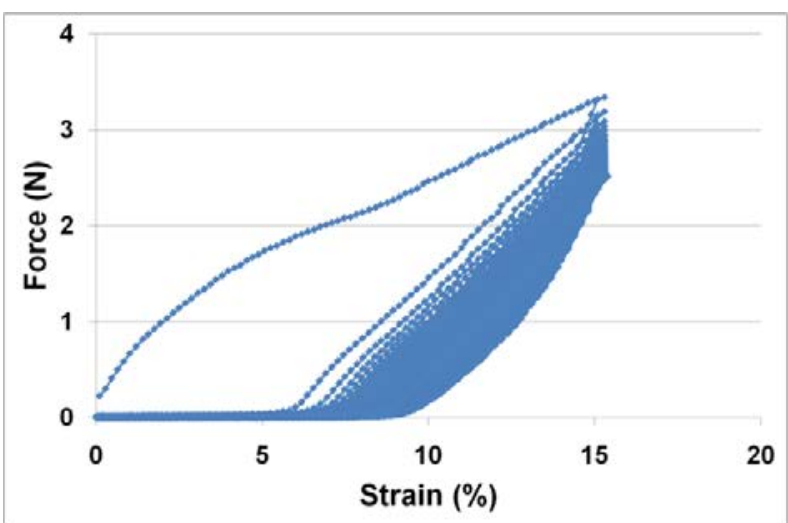

(a)

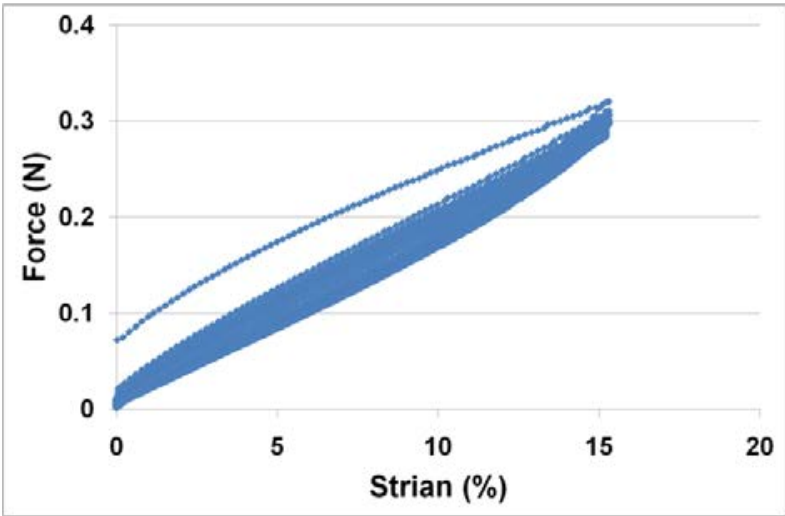

(c)

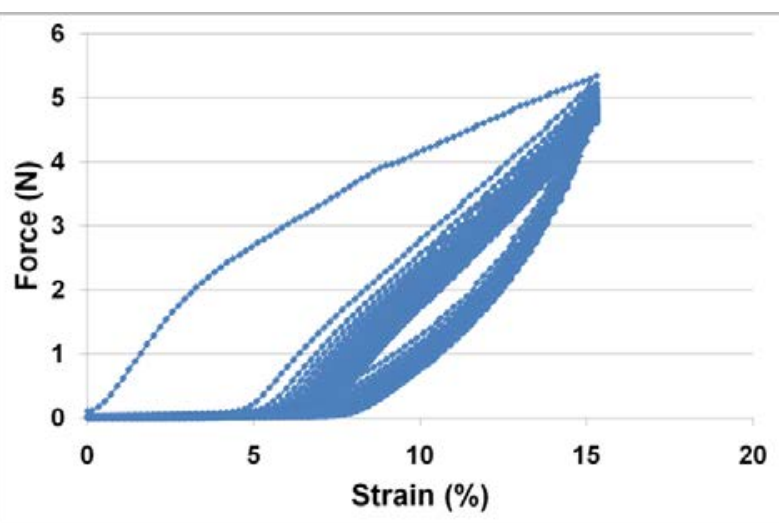

(b)

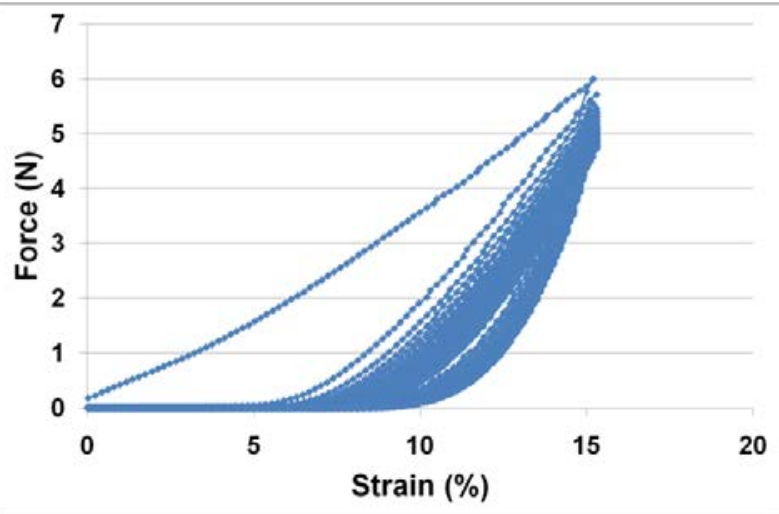

(d)

Figure 3: Typical force-strain curve over 100 loading-unloading cycles at $10 \mathrm{~mm} / \mathrm{min}$ (a) Prolene ${ }^{\circledR}$ (b) Supramid Extra ${ }^{\circledR}$ II (c) Visitec ${ }^{\circledR}$ SFSS (d) Mersilene ${ }^{\circledR}$ mesh

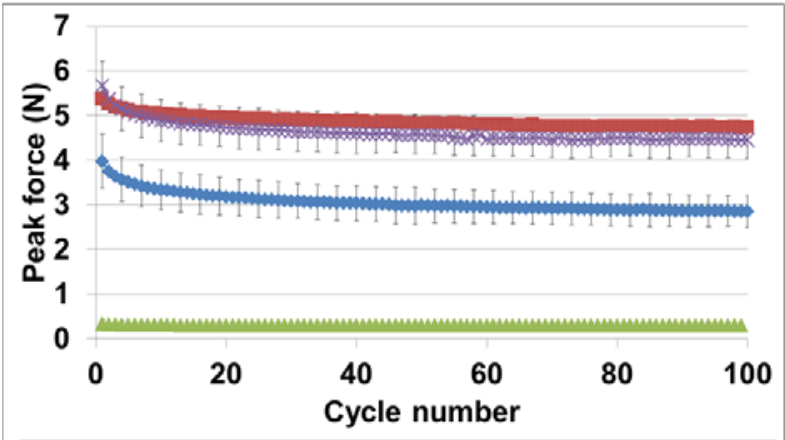

$\leftarrow$ Prolene $=$ Supramid Extra II $₫$ Visitec SFSS $*$ Mersilene mesh

(a)

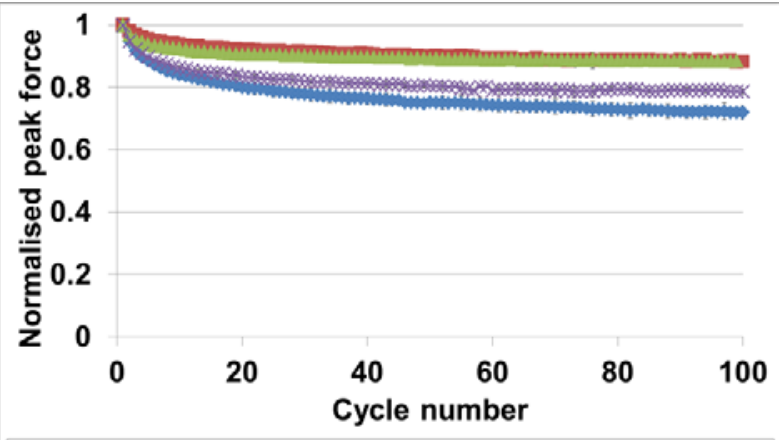

$\leftarrow$ Prolene - Supramid Extra II $₫$ Visitec SFSS $*$ Mersilene mesh

(b)

Figure 4: Preconditioning test results for brow-suspension materials as a function of the number of cycles (a) averaged peak force (b) normalised peak force 


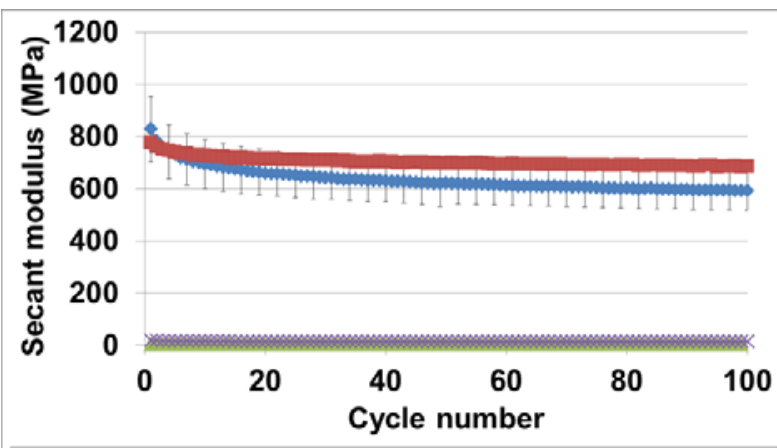

$\rightarrow$ Prolene - Supramid Extra II $\star$ Visitec SFSS $*$ Mersilene mesh

(a)

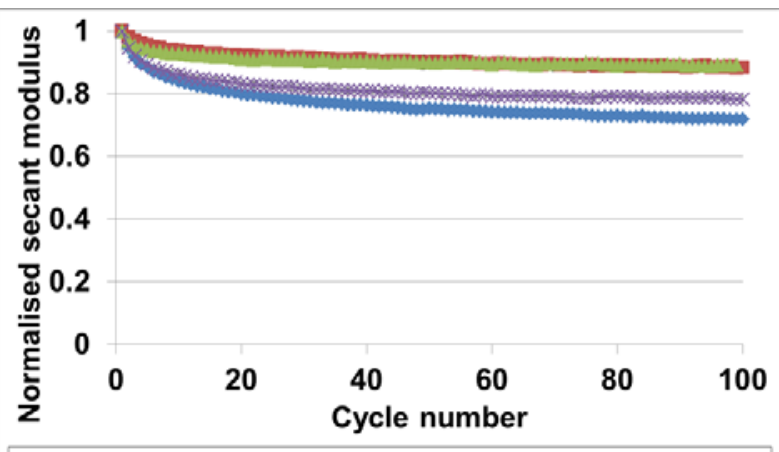

$\rightarrow$ Prolene - Supramid Extra II $₫$ Visitec SFSS $*$ Mersilene mesh

(b)

Figure 5: Preconditioning test results for brow-suspension materials as a function of the number of cycles (a) averaged secant modulus (b) normalised secant modulus

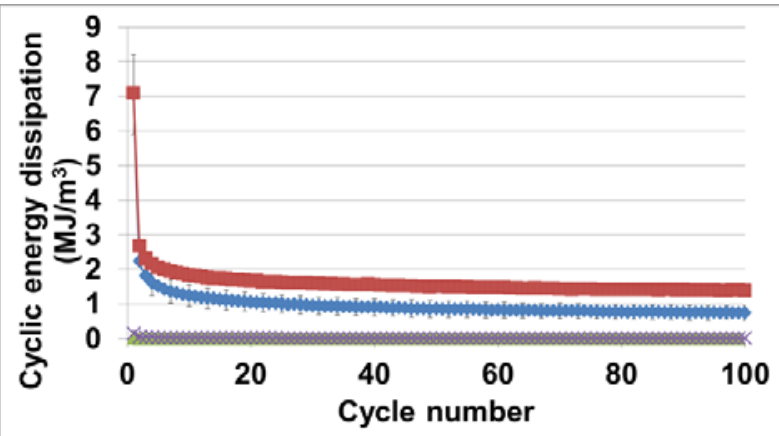

$\leftarrow$ Prolene - Supramid Extra II $₫$-Visitec SFSS $*$ Mersilene mesh

(a)

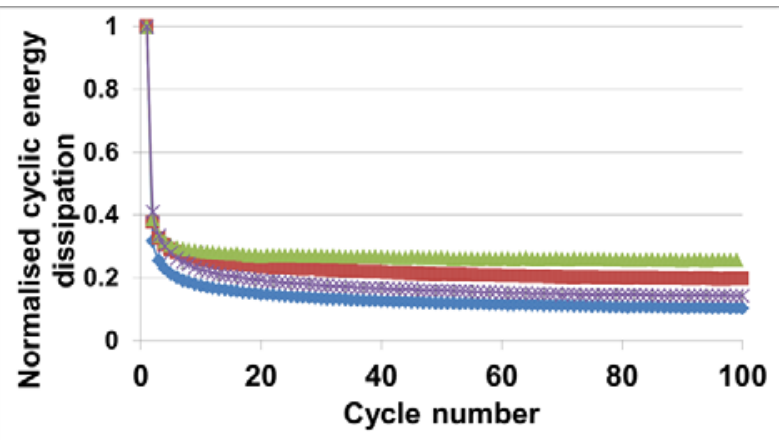

$\leftarrow$ Prolene $=$ Supramid Extra II $\star$ Visitec SFSS $*$ Mersilene mesh

(b)

Figure 6: Preconditioning test results for brow-suspension materials as a function of the number of cycles (a) averaged cyclic energy dissipation (b) normalised cyclic energy dissipation 

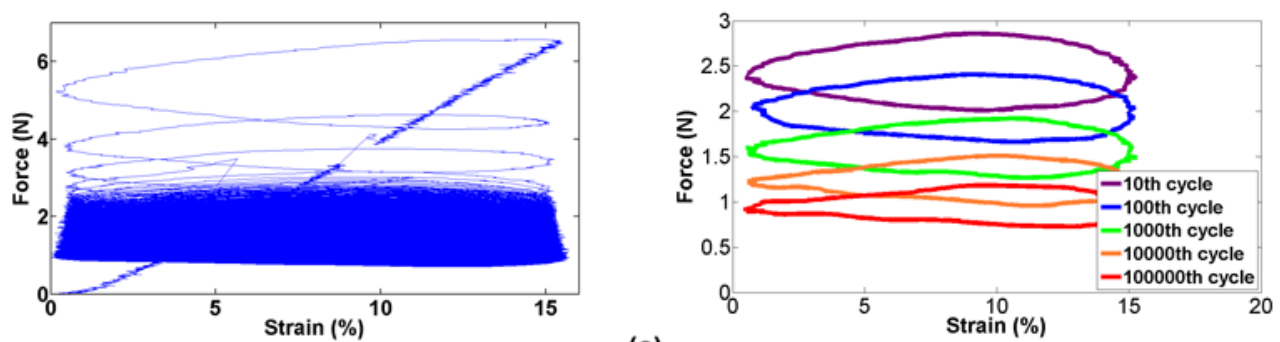

(a)
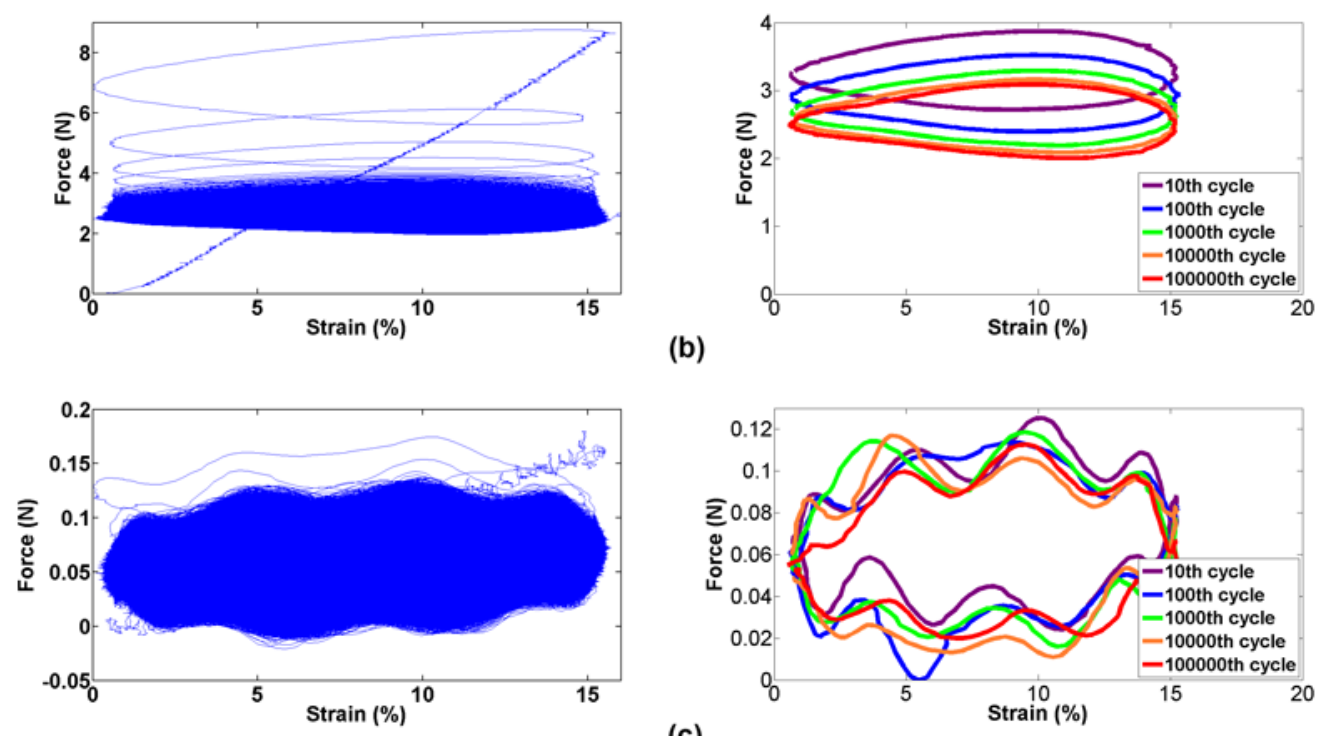

(b)
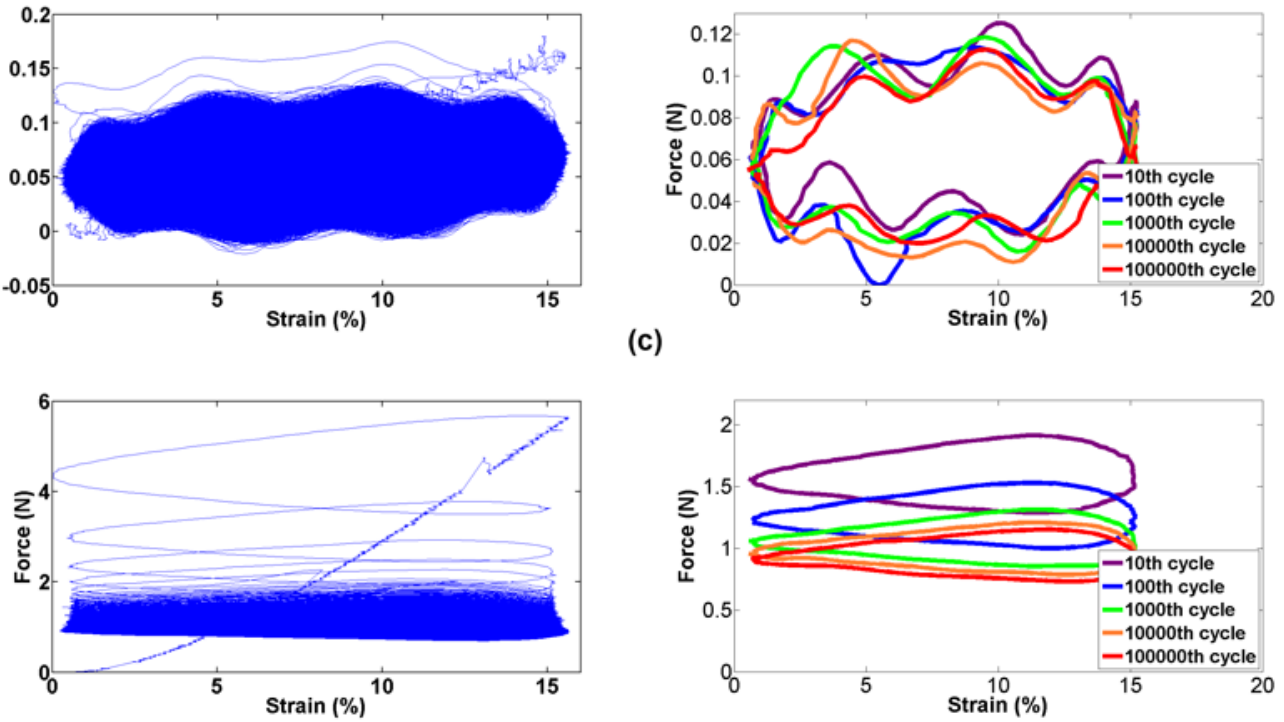

(d)

Figure 7: Typical force-strain curves over 100,000 cycles (a) Prolene ${ }^{\circledR}$ (b) Supramid Extra ${ }^{\circledR}$ II (c) Visitec ${ }^{\circledR}$ SFSS (d) Mersilene ${ }^{\circledR}$ mesh 


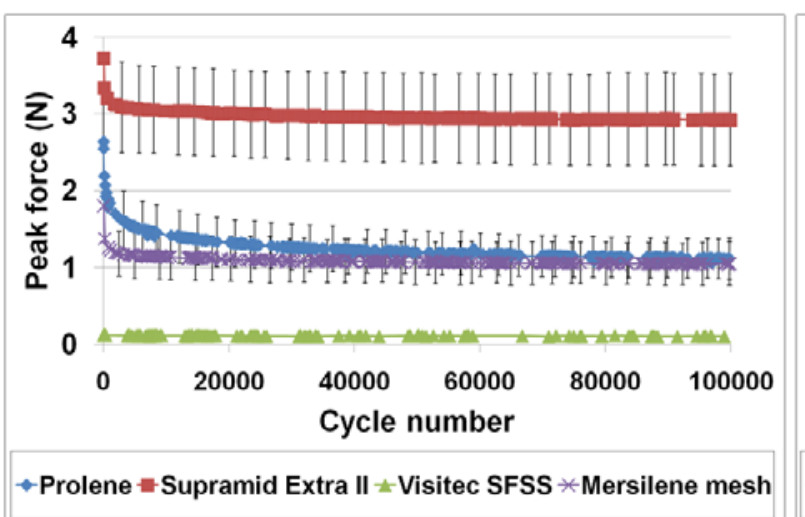

(a)

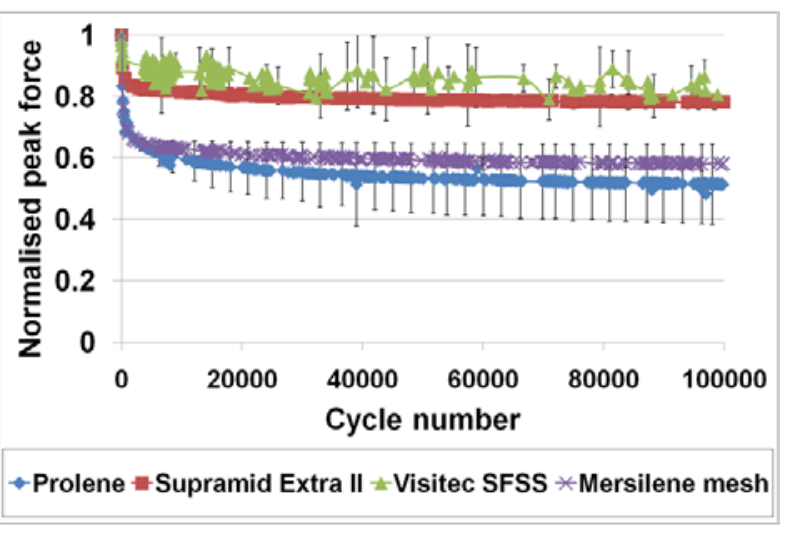

(b)

Figure 8: Fatigue test results for brow-suspension materials as a function of the number of cycles (a) averaged peak force (b) normalised peak force

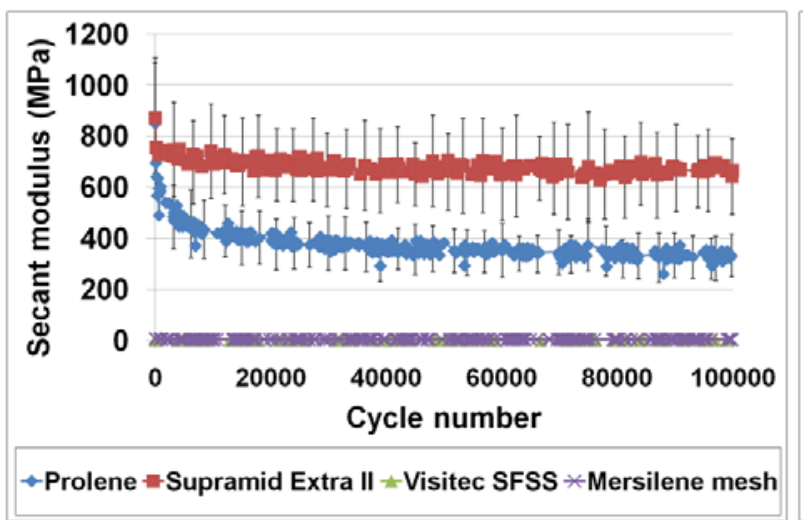

(a)

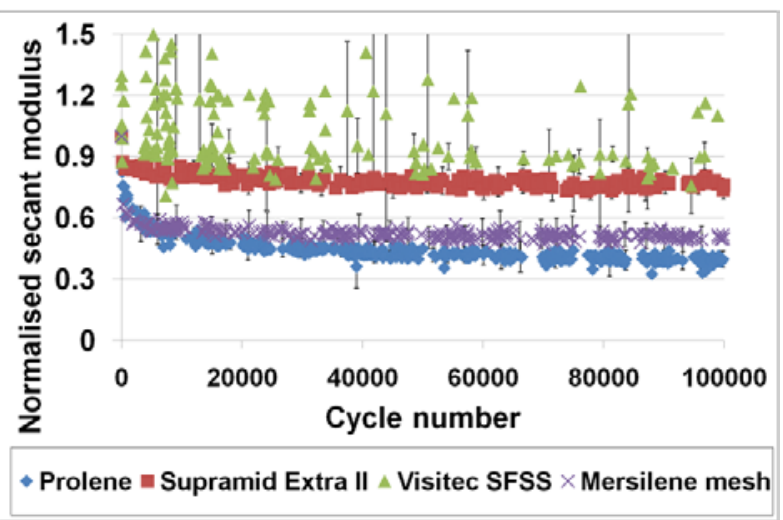

(b)

Figure 9: Fatigue test results for brow-suspension materials as a function of the number of cycles (a) averaged secant modulus (b) normalised secant modulus

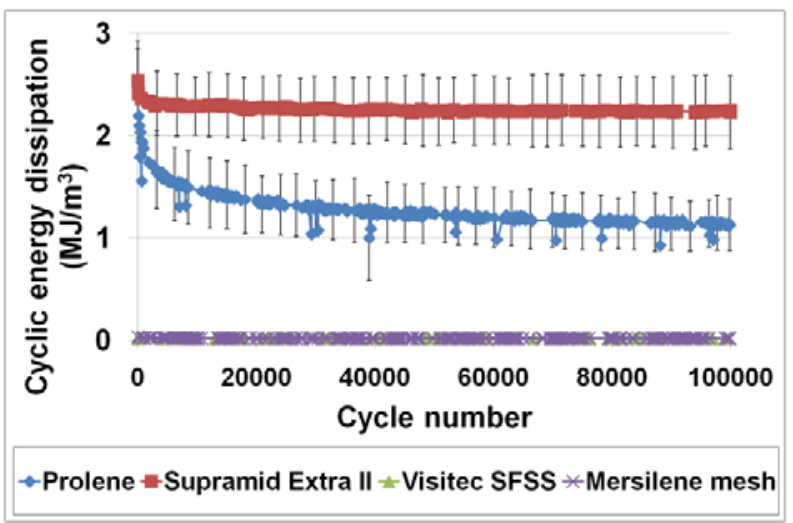

(a)

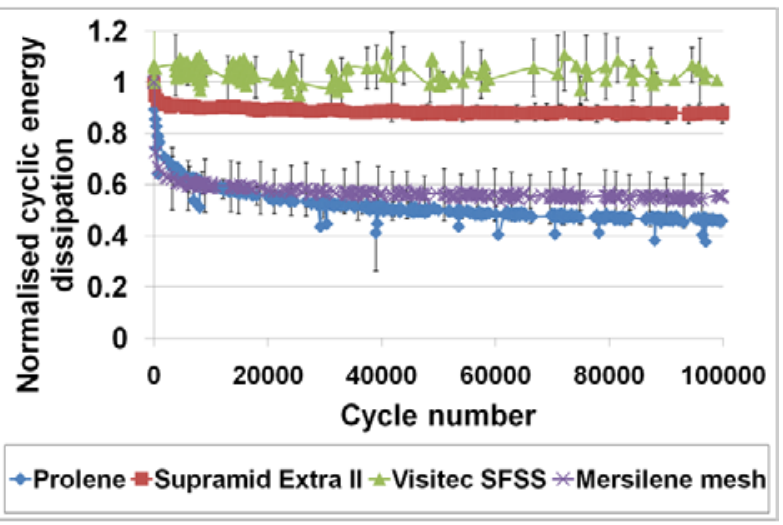

(b)

Figure 10: Fatigue test results for brow-suspension materials as a function of the number of cycles (a) averaged cyclic energy dissipation (b) normalised cyclic energy dissipation 


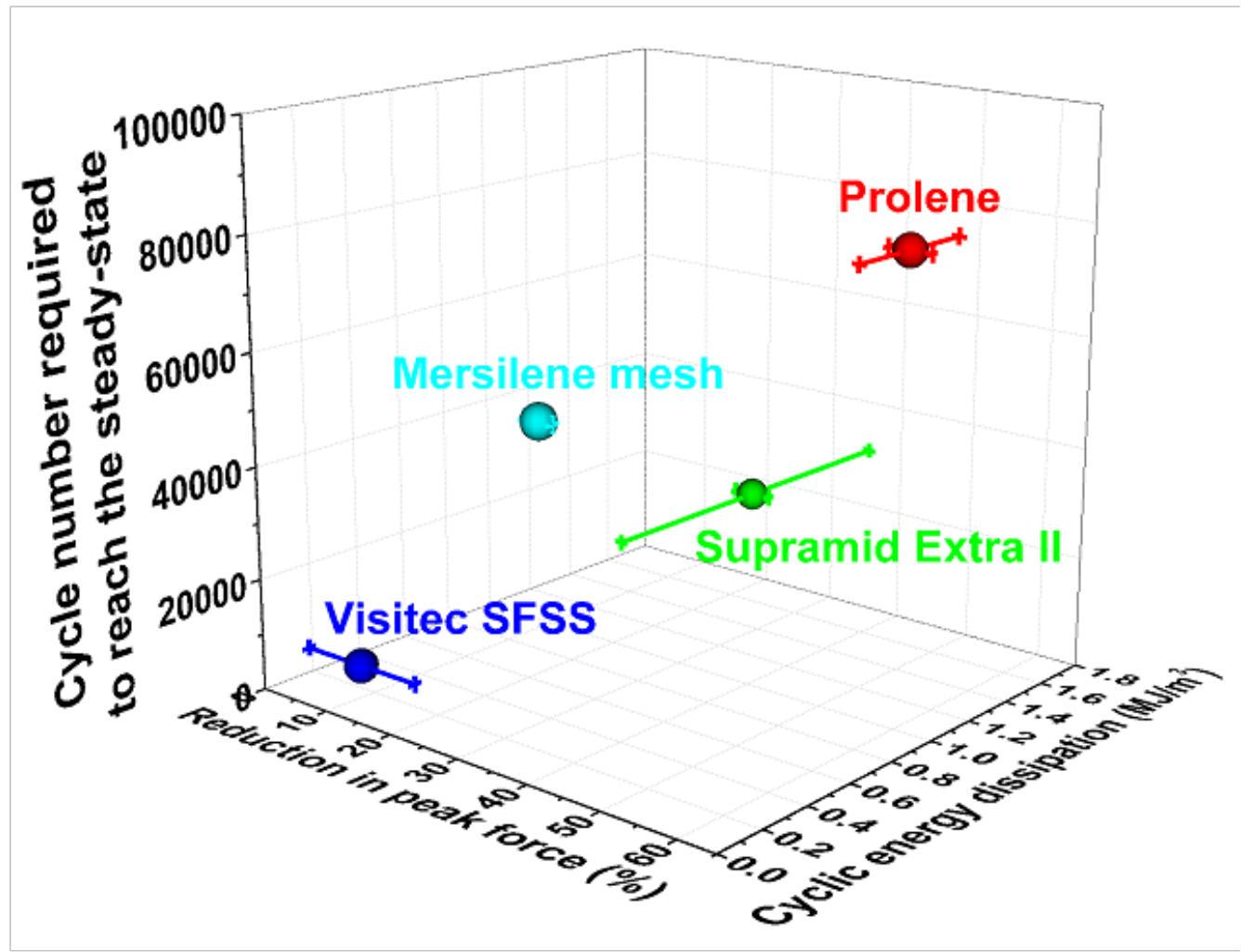

Figure 11: Comparison of various parameters obtained after 100,000 cycle fatigue tests of the brow-suspension materials investigated in this work (the error bars represent s.d. values)

Table 1: Commonly-used synthetic brow-suspension materials investigated in this study

\begin{tabular}{|c|c|c|c|}
\hline Material & Appearance & Type & Dimensions \\
\hline Prolene ${ }^{\circledR}$ & & Polypropylene & Diameter of $\sim 0.2 \mathrm{~mm}$ \\
\hline $\begin{array}{l}\text { Supramid } \\
\text { Extra }^{\circledR} \text { II }\end{array}$ & & $\begin{array}{c}\text { Polyamide } \\
\text { multifilaments }\end{array}$ & $\begin{array}{c}\text { Overall diameter of } \sim 0.24 \mathrm{~mm} \text {, } \\
\text { enclosing } \sim 50 \text { twisted filaments (each } \\
\text { diameter } \sim 20 \mu \mathrm{m} \text { ) }\end{array}$ \\
\hline $\begin{array}{c}\text { Visitec }^{\circledR} \\
\text { SFSS }\end{array}$ & & $\begin{array}{l}\text { Silicone solid } \\
\text { rod }\end{array}$ & Diameter of $\sim 0.8 \mathrm{~mm}$ \\
\hline $\begin{array}{c}\text { Mersilene }^{\circledR} \\
\text { mesh }\end{array}$ & & $\begin{array}{l}\text { Polyethylene } \\
\text { terephthalate } \\
\text { polyester } \\
\text { woven mesh }\end{array}$ & $\begin{array}{l}\text { Thickness }=0.26 \mathrm{~mm} \text { with varying } \\
\text { width }(6-8 \mathrm{~mm}) \text {; Oval-shaped pores } \\
\text { with long axis of } \sim 1.4 \mathrm{~mm} \text { and short } \\
\text { axis of } \sim 0.75 \mathrm{~mm}\end{array}$ \\
\hline
\end{tabular}


Table 2: Uniaxial displacement-controlled fatigue test program

\begin{tabular}{|c|c|}
\hline Segment Number & Process \\
\hline 1 & Position hold at 0 mm (=0\% strain) for 1s \\
\hline 2 & $\begin{array}{c}\text { Displacement-controlled sinusoidal oscillation } \\
\text { between 0 mm and } 1.5 \mathrm{~mm} \text { (i.e. 0-15\% strain with } \\
\text { mean strain of } 7.5 \%) \text { at } 6.5 \mathrm{~Hz} \text { for } 100,000 \text { cycles }\end{array}$ \\
\hline 3 & Position hold for $1 \mathrm{~s}$ \\
\hline 4
\end{tabular}

Table 3: Summary of stress-relaxation test results for each of four synthetic brow-suspension materials (the values are mean \pm s.d.)

\begin{tabular}{|c|c|c|c|}
\hline Material & Peak Force (N) & Force Reduction (\%) & Relaxation Ratio \\
\hline Prolene $^{\circledR}$ & $4.29 \pm 0.29$ & $69.7 \pm 4.7$ & $3.36 \pm 0.49$ \\
\hline Supramid Extra $^{\circledR}$ II & $4.70 \pm 0.74$ & $40.5 \pm 4.4$ & $1.69 \pm 0.12$ \\
\hline Visitec $^{\circledR}$ SFSS & $0.26 \pm 0.09$ & $22.1 \pm 1.5$ & $1.28 \pm 0.03$ \\
\hline Mersilene $^{\circledR}$ Mesh & $4.08 \pm 0.27$ & $31.7 \pm 2.4$ & $1.47 \pm 0.05$ \\
\hline
\end{tabular}

Table 4: Summary of creep test results for each of the synthetic brow-suspension materials (the values are mean \pm s.d.)

\begin{tabular}{|c|c|c|c|}
\hline $\begin{array}{l}\text { Constant } \\
\text { Load (N) }\end{array}$ & Material & Initial Strain (\%) & Creep Ratio \\
\hline \multirow{4}{*}{0.5} & Prolene $^{\circledR}$ & $1.80 \pm 0.18$ & $2.24 \pm 0.12$ \\
\hline & Supramid Extra $\left.{ }^{(}\right)$II & $1.31 \pm 0.16$ & $1.30 \pm 0.10$ \\
\hline & Visitec $^{(R)}$ SFSS & $43.6 \pm 6.3$ & $1.14 \pm 0.06$ \\
\hline & Mersilene ${ }^{\circledR}$ Mesh & $3.19 \pm 0.20$ & $1.11 \pm 0.03$ \\
\hline \multirow{4}{*}{2} & Prolene $^{(R)}$ & $12.2 \pm 2.3$ & $1.77 \pm 0.11$ \\
\hline & Supramid Extra ${ }^{\circledR}$ II & $7.78 \pm 0.78$ & $1.36 \pm 0.03$ \\
\hline & Visitec $^{(B)}$ SFSS & $275 \pm 51$ & $1.13 \pm 0.02$ \\
\hline & Mersilene ${ }^{\circledR}$ Mesh & $9.47 \pm 0.64$ & $1.13 \pm 0.01$ \\
\hline
\end{tabular}


Table 5: Summary of preconditioning test results for each material (the values are mean \pm s.d. and 'Preconditioned number of cycles' refers to the number of cycles required to reach a steady-state in relation to the values of peak force and cyclic energy dissipation)

\begin{tabular}{|c|c|c|c|c|}
\hline & Prolene $^{\circledR}$ & $\begin{array}{l}\text { Supramid } \\
\text { Extra }^{\circledR} \text { II }\end{array}$ & Visitec ${ }^{\circledR}$ SFSS & $\begin{array}{c}\text { Mersilene }^{\circledR} \\
\text { mesh }\end{array}$ \\
\hline $\begin{array}{c}\text { Preconditioned } \\
\text { number of cycles }\end{array}$ & $\sim 90$ & $\sim 40$ & $\sim 20$ & $\sim 60$ \\
\hline $\begin{array}{c}\text { Peak force at } 1^{\text {st }} \\
\text { cycle }(\mathrm{N})\end{array}$ & $3.97 \pm 0.60$ & $5.37 \pm 0.17$ & $0.33 \pm 0.09$ & $5.67 \pm 0.55$ \\
\hline $\begin{array}{l}\text { Peak force at } 100^{\text {th }} \\
\text { cycle }(\mathrm{N})\end{array}$ & $2.85 \pm 0.36$ & $4.74 \pm 0.14$ & $0.29 \pm 0.07$ & $4.46 \pm 0.42$ \\
\hline $\begin{array}{l}\text { Reduction in peak } \\
\text { force over } 100 \\
\text { cycles (\%) }\end{array}$ & $28.0 \pm 2.2$ & $11.7 \pm 2.0$ & $11.5 \pm 1.5$ & $21.3 \pm 0.8$ \\
\hline $\begin{array}{l}\text { Secant modulus at } \\
\text { 1st cycle (MPa) }\end{array}$ & $828 \pm 126$ & $776 \pm 25$ & $4.31 \pm 1.17$ & $20.0 \pm 4.8$ \\
\hline $\begin{array}{l}\text { Secant modulus at } \\
100^{\text {th }} \text { cycle (MPa) }\end{array}$ & $593 \pm 76$ & $685 \pm 20$ & $3.84 \pm 0.99$ & $15.6 \pm 3.5$ \\
\hline $\begin{array}{l}\text { Cyclic energy } \\
\text { dissipation at } 1^{\text {st }} \\
\text { cycle }\left(\mathrm{MJ} / \mathrm{m}^{3}\right)\end{array}$ & $7.05 \pm 1.16$ & $7.08 \pm 0.04$ & $0.018 \pm 0.002$ & $0.149 \pm 0.047$ \\
\hline $\begin{array}{c}\text { Cyclic energy } \\
\text { dissipation at } 100^{\text {th }} \\
\text { cycle }\left(\mathrm{MJ} / \mathrm{m}^{3}\right)\end{array}$ & $0.74 \pm 0.21$ & $1.39 \pm 0.09$ & $0.005 \pm 0.001$ & $0.021 \pm 0.004$ \\
\hline $\begin{array}{l}\text { Reduction in cyclic } \\
\text { energy dissipation } \\
\text { over } 100 \text { cycles (\%) }\end{array}$ & $89.6 \pm 1.2$ & $80.4 \pm 1.2$ & $74.3 \pm 0.7$ & $85.8 \pm 1.7$ \\
\hline
\end{tabular}


Table 6: Summary of fatigue test results for each of the synthetic brow-suspension materials (the values are mean \pm s.d.)

\begin{tabular}{|c|c|c|c|c|}
\hline & Prolene ${ }^{\circledR}$ & $\begin{array}{l}\text { Supramid } \\
\text { Extra }^{\circledR} \text { II }\end{array}$ & Visitec $^{\circledR}$ SFSS & $\begin{array}{c}\text { Mersilene }^{\circledR} \\
\text { mesh }\end{array}$ \\
\hline $\begin{array}{l}\text { Number of cycles } \\
\text { required to reach the } \\
\text { steady-state }\end{array}$ & 80000 & 20000 & 10000 & 60000 \\
\hline $\begin{array}{l}\text { Peak force at } 10^{\text {th }} \\
\text { cycle }(\mathrm{N})\end{array}$ & $2.64 \pm 0.66$ & $3.73 \pm 0.68$ & $0.13 \pm 0.01$ & $1.80 \pm 0.47$ \\
\hline $\begin{array}{c}\text { Peak force at } \\
100,000^{\text {th }} \text { cycle }(\mathrm{N})\end{array}$ & $1.11 \pm 0.25$ & $2.92 \pm 0.61$ & $0.11 \pm 0.01$ & $1.06 \pm 0.28$ \\
\hline $\begin{array}{c}\text { Reduction in peak } \\
\text { force over } \sim 100,000 \\
\text { cycles (\%) }\end{array}$ & $57.8 \pm 2.8$ & $21.9 \pm 2.5$ & $15.2 \pm 8.2$ & $41.6 \pm 1.8$ \\
\hline $\begin{array}{c}\text { Secant modulus at } \\
100,000^{\text {th }} \text { cycle }(\mathrm{MPa})\end{array}$ & $334 \pm 91$ & $649 \pm 151$ & $2.14 \pm 0.17$ & $4.93 \pm 1.87$ \\
\hline $\begin{array}{c}\text { Cyclic energy } \\
\text { dissipation at } \\
100,000^{\text {th }} \text { cycle } \\
\left(\mathrm{MJ} / \mathrm{m}^{3}\right)\end{array}$ & $1.11 \pm 0.25$ & $1.65 \pm 0.67$ & $\begin{array}{c}0.0167 \pm \\
0.0004\end{array}$ & $\begin{array}{c}0.0190 \pm \\
0.0089\end{array}$ \\
\hline
\end{tabular}

